\section{New Jersey rebuffs loan to fund stem-cell research}

On 6 November, voters in New Jersey rejected a proposal to borrow $\$ 450$ million to fund stem-cell research. The move is the first time a bond measure has been defeated by voters in the state in 17 years. Pre-election polling had indicated that the measure would win easily, which made the $53 \%$ to $47 \%$ loss a startling rebuke to supporters.

Political observers suggest that fiscal concerns might have been a factor: New Jersey is $\$ 30$ billion in debt.

The vote came two weeks after construction work began on the state's first stem-cell institute. The 18-storey Stem Cell Institute of New Jersey in New Brunswick is being financed by $\$ 270$ million that state lawmakers approved in 2006. The $\$ 450$ million was to have funded research grants over ten years.

\section{Accelerator will bring antiproton beam online}

$\mathrm{A} € 1$.2-billion (US\$1.7-billion) particle accelerator to be built in Germany has been given the final go-ahead. The Facility for Antiproton and Ion Research (FAIR) will investigate exotic atomic nuclei and examine the states of matter in the moments after the Big Bang.

The 15-nation consortium behind the project gave it the green light on 7 November. Construction is scheduled to begin in late 2008 and should be complete by 2016 .

FAIR will feature a double-ring synchrotron with a circumference of 1,100 metres connected to the existing GSI facility in Darmstadt, Germany. It will be able to accelerate ions as heavy as uranium, and will also generate the world's most powerful antiproton beam.

Germany is picking up three-quarters of the price tag, the rest will be paid for by the partner countries, which include China, France, India, Italy, Russia and Britain.

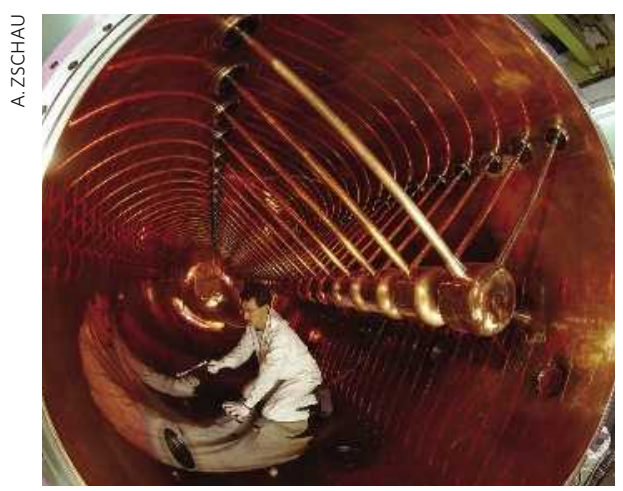

The GSI's UNILAC will serve as a pre-accelerator for a planned double-ring synchrotron.

\title{
Lunar pole captured on Moon video
}

Areas of the Moon's north polar region pop out in stark relief in this image taken by the Japanese lunar mission Kaguya (Selene).

The Japanese

Aerospace Exploration Agency and the Japan Broadcasting

Corporation, both based in Tokyo, teamed up to broadcast high-

definition television footage from Kaguya. This shot, taken on 31 October, is a still from the video of two short clips available at http://www.jaxa.jp/topics/2007/11_e.html.

Taken from an elevation of 100 kilometres, it shows the landscape below the probe as it moves from the Oceanus Procellarum region towards the lunar north pole.

\section{Knowledge gaps pour cold water on sea fertilization}

The parties to the London Convention, the international treaty governing ocean dumping, have agreed that large-scale ocean 'fertilization' is currently not justified given gaps in scientific knowledge.

Adding iron, phosphate or urea can stimulate plankton growth in nutrientpoor parts of the ocean - thereby sucking down carbon dioxide from the atmosphere and potentially helping to combat climate change. But critics warn that the ecological impact is poorly understood, and at its meeting in London last week, the convention endorsed concerns issued in June by its scientific advisory group.

Environmentalists last week also raised concerns over an Australian company's plan to test its carbon-sequestration technology in Philippine waters. Ocean Nourishment Corporation (ONC) of Pyrmont, New South Wales, is currently in discussions with Philippine authorities over dumping 500 tonnes of dissolved urea, a nitrogen-based fertilizer, in the Sulu Sea between Borneo and the Philippines.

\section{Patient privacy rules hamper US research}

US biomedical research is being hampered by privacy rules introduced in 2003, according to a survey of epidemiologists.

More than 1,500 'eligible professionals' took part in the survey, and $68 \%$ of them said that research has been made more difficult by the privacy rules (R. B. Ness J. Am. Med. Assoc. 298, 2164-2170; 2007). The rules are meant to ensure that medical records remain personal and private. But only $26 \%$ of the epidemiologists in the survey thought that the rules have enhanced confidentiality.
The survey, conducted by the Joint Policy Committee for the Societies of Epidemiology, gauged the effect of the Health Insurance Portability and Accountability Act Privacy Rule. This allows disclosure of patient records for research only if the scientist has authorization from the patient or has been granted a waiver by an institutional review board.

\section{Cap on overheads may put universities off defence}

The US Congress has set a limit on overhead expenses for research done at universities on behalf of the Department of Defense.

The provision, approved in a final version of the defence-spending bill on 8 November, says that no more than $35 \%$ of research funding can be spent on costs such as maintenance and utilities. The bill now goes to President Bush to be signed into law.

"It's going to be a disincentive for the nation's best universities to conduct defence research," says Barry Toiv, a spokesman for the Association of American Universities in Washington DC. After the Department of Agriculture set a similar cap, he notes, fewer universities applied for government grants.

Currently, overhead expense rates are negotiated individually with the university department - the average is $34 \%$, according to the latest survey from the Council on Governmental Relations.

\section{Correction}

The photo that accompanied our News In Brief story 'Argo systems makes a splash with final float' (Nature 450, 148; 2007) should have been captioned as being a demonstration deployment, not the actual 3,000th float, and credited to Alan Blacklock, National Institute of Water and Atmospheric Research, New Zealand. In addition, the Argo data are accessible to all nations - not just the ones that participate in the project, which will continue to deploy additional floats over time to maintain the array. 